International Journal of Life Sciences
Available online at http://sciencescholar.us/journal/index.php/ijls
Vol. 2 No. 2, August 2018, pages: 73 82
e-ISSN: 2550-6986, p-ISSN: 2550-6994
https://doi.org/10.29332/ijls.v2n2.179

\title{
Increasing Nutrition Value of Fermented Rice Hull through Biofermentation of Lactobacillus Complex Bacteria Supplemented
}

\author{
Ida Bagus Gaga Partama a, Tjokorda Gede Belawa Yadnya b, Anak Agung Ayu Sri Trisnadewi c, \\ I Ketut Sukada d
}

Article history: Received 10 March 2018, Accepted in revised form 25 June 2018, Approved 21 July 2018, Available online 31 August 2018

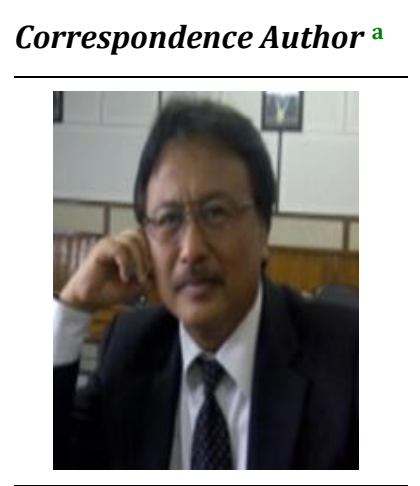

Keywords

Bali duck;

Betle leaf meal;

Nutrition value;

Fermented rice hull;

Blood antioxidant profile;

\begin{abstract}
An experiment was carried out to determine the nutrition value and the effect of blood antioxidant profile of Bali duck of fermented rice hull through biofermentation and supplemented with betle leaf meal. A completely randomized design (CRD) with five treatments diets and four replications were used and each replicate consisted of five ducks. The treatment was diet A as control (diet without rice hull and betle leaf meal), diet $B$ containing $10 \%$ rice hull, diet $C$ containing $10 \%$ fermented rice hull, diet $\mathrm{D}$ containing $10 \%$ rice hull and betle leaf meal, and diet $\mathrm{E}$ containing $10 \%$ fermented rice hull and betle leaf meal. The variables observed were: nutrition value of fermented rice hull, performance, and blood antioxidant profile. The results showed that fermented rice hull could improve the content of crude protein from $4.66 \%$ to $7.49 \%$; energy extract $1.99 \%$ to $2.88 \%$; nitrogen-free extract $8.66 \%$ to $19.01 \%$; ash $16.41 \%$ to $23.53 \%$ and decrease the crude fiber 43.59 to $21.01 \%$. Treatments A, B, C, D, and E were not significantly different on feed consumption $(\mathrm{P}>0.05)$. Provision of diet $\mathrm{E}$ can result in the highest of ration digestibility, antioxidant capacity, and final weight $(\mathrm{P}<0.05)$, and could increase of antioxidant capacity, superoxide dismutase (SOD) and decrease malondialdehyde $(\mathrm{P}<0.05)$ of Bali duck blood. It could be concluded that the fermented rice hull supplemented by Piper betle could improve the nutrition value of rice hull, performance, and blood antioxidant profile of Bali ducks.
\end{abstract}

e-ISSN: 2550-6986, p-ISSN: 2550-6994@C Copyright 2018. The Author. SS Journals Published by Universidad Técnica de Manabí. This is an open-access article under the CC BY-SA 4.0 license (https://creativecommons.org/licenses/by-sa/4.0/) All rights reserved.

a Faculty of Animal Husbandry, Udayana University, Indonesia

b Faculty of Animal Husbandry, Udayana University, Indonesia

c Faculty of Animal Husbandry, Udayana University, Indonesia

d Faculty of Animal Husbandry, Udayana University, Indonesia 


\section{Contents}

Abstract

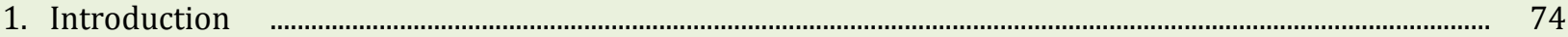

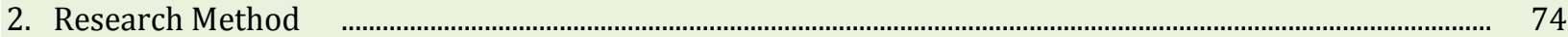

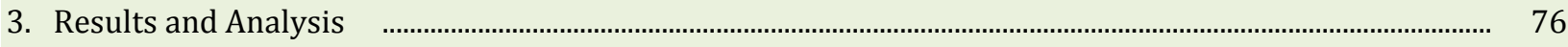

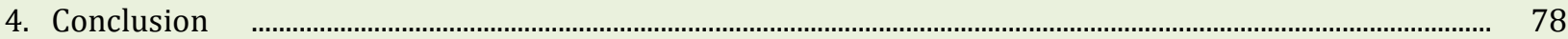

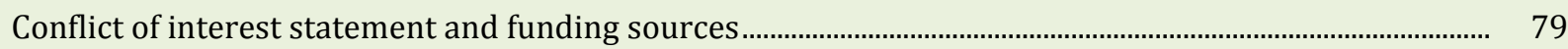

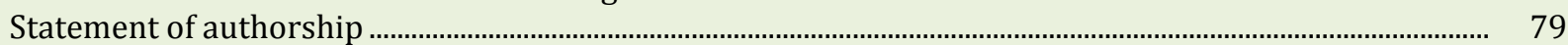

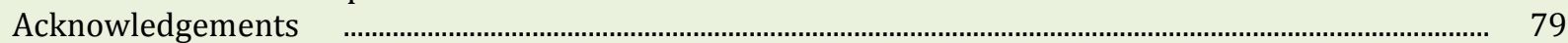

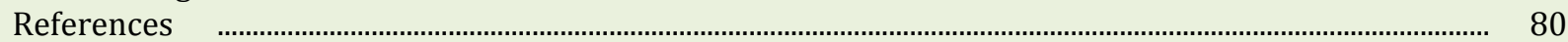

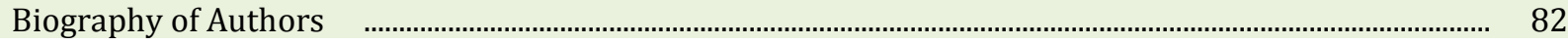

\section{Introduction}

The useful of rice hull for alternative feed needs to improve because the supply is fairly high. The grain milling into rice produced $17 \%$ of rice hull (Lubis, 1992). Rice hull contain high crude fiber, so it couldn't digest by monogastric such as duck with crude fiber content 43.3\% and crude protein 3.8\% (Bidura, 2007). To increase the nutrients value of diet, it needs biofermentation of EM-4 (Effective microorganisms-4) (Wididana and Higa, 1993). Yadnya et al. (2007) found that EM-4 solution biofermentation in sawdust changed crude fiber from $81,91 \%$ to $48,40 \%$, crude protein from $0,90 \%$ to $8.10 \%$, ether extract from the $0.32 \%$ to $2.30 \%$. Suwidjayana et al. ( 2005 ) reported that the provision of $10 \%$ and $20 \%$ of sawdust fermented with the EM-4 solution could increase ration digestibility and not affecting the performance of Bali ducks. Nuriyasa et al. (1998) found that provision of Effective Microorganisms-4 (EM-4) to mannihot tuber which contains pancreas extract could increase in vitro digestibility. Roni et al. (2006) reported that provision of a diet containing $5.97 \%$ rice hull and urea resulted slaughter weight lower than control treatment, but after supplemented by starbio resulted in no significant different $(\mathrm{P}>0.05)$ on slaughter weight and final weight.

Improving animal productivity needs diet component which content of antioxidant compound such as betle (Piper betle L.) leaf which contains flavonoid, betlephenol, seskuitefen, and kavikol (Adm, 2013), (Dewi, et al.: 2018). The antioxidant compound could neutralize free radical and also affect the metabolism processes in the body (Kumalaningsih, 2008). Sumardika and Jawi (2011) reported that offering of Ipomoea batatas L. leaf extract could improve lipid profile and increase the superoxide dismutase (SOD) value. Yadnya et al. (2015) reported that offering of diets containing fermented Ipomoea batatas L. skin could increase performance, feed antioxidant capacity and improve the antioxidant profile of Bali duck. Susila et al. (2016) reported that offering of fermented rice hull supplemented with Ipomoea batatas L. leaf meal could increase digestibility, performance, antioxidant capacity, and superoxide dismutase (SOD) but decrease Malondialdehyde (MDA) of Bali duck meat (Ogu, et al.: 2017), (Saxena: 2017).

The research was carried out to study the effort to increase the nutrition value of fermented rice hull supplemented with Piper betle L leaf meal and the effect of blood antioxidant profile of Bali duck.

\section{Research Method}

\section{Material and Method}

The research was conducted at Guwang Village, Gianyar Regency, Bali Province for 10 weeks. Nutrition value analysis of fermented rice hull consisted of crude protein, ether extract, crude fiber, nitrogen-free extract, ash and gross energy and carried out in the Laboratory of Nutrition, Faculty of Animal Husbandry, Udayana University for four weeks. Test of blood antioxidant profile was carried out at the Analytic Laboratory, Udayana University for two weeks. 
Biofermentation with Lactobacillus complex Bacteria Solution of Rice Hull Supplemented with Betle Leaf Mea

Rice hull was mashed and mixed with Effective Microorganisms-4 (EM-4), urea, and molasses solution, then inserted into sacks and incubated for one week. After being fermented then dried and ready to use for the experiment.

\section{Experimental Design}

The experiment used a completely randomized design (CRD) with five treatments: the control diet (A), diet containing $10 \%$ rice hull (B), diet containing $10 \%$ fermented rice hull (C), diets containing $10 \%$ rice hull and $0.20 \%$ betle leaf meal (D), and diet containing $10 \%$ fermented rice hull and $0.20 \%$ betle leaf meal (E). Each treatment consists of four replicates and each replicate consist of five ducks with homogenous weight, so there were 100 male ducks with three weeks old. Diet consisted of yellow corn, soybean, copra meal, rice bran, fish meal, coconut oil, salt $(\mathrm{NaCl})$ and $\mathrm{B} 12$ mineral. Rice hull with fermented or unfermented and meal leaf betle was allocated according to the treatments. The ingredient composition of treatments shown in Table 1 and the chemical composition is shown in Table 2.

This experiment used two floors battery colony cages system with 20 partitions. Each partition of the cages was $70 \mathrm{~cm}$ length, $65 \mathrm{~cm}$ width, and $70 \mathrm{~cm}$ height. Each partition was equipped with food trays and drinking water. Trays made from bamboo and located at the external part of the cages.

Table 1

Diet composition of Bali duck (age 3 - 10 weeks)

\begin{tabular}{lccccc}
\hline \multirow{2}{*}{ Ingredients $(\%)$} & \multicolumn{5}{c}{ Treatments } \\
\cline { 2 - 6 } & $\mathrm{A}$ & $\mathrm{B}$ & $\mathrm{C}$ & $\mathrm{D}$ & $\mathrm{E}$ \\
\hline Yellow corn & 55.36 & 49.98 & 49.98 & 49.98 & $49, .8$ \\
Soybean & 9.37 & 12.45 & 12.45 & 12.45 & 12.45 \\
Copra meal & 11.31 & 9.82 & 9.82 & 9.82 & 9.82 \\
Fish meal & 10.13 & 8.10 & 8.10 & 8.10 & 8.10 \\
Rice bran & 13.26 & 7.00 & 7.00 & 6.80 & 6.80 \\
Rice hull & - & 10.00 & $10.00^{*}$ & 10.00 & $10.00^{*}$ \\
Betle leaf meal & - & - & - & 0,20 & 0,20 \\
Coconut oil & - & 2.00 & 2.00 & 2.00 & 2.00 \\
B12 Mineral & 0.50 & 0.50 & 0.50 & 0.50 & 0.50 \\
NaCl & 0.15 & 0.15 & 0.15 & 0.15 & 0.15 \\
\hline Total & 100 & 100 & 100 & 100 & 100 \\
\hline
\end{tabular}

Notes:

$\mathrm{A}=$ control diet (without rice hull and betle leaf meal); $\mathrm{B}=$ diet containing $10.0 \%$ rice hull; $\mathrm{C}=$ diet containing $10 \%$ fermented rice hull; $\mathrm{D}=$ diet containing $10 \%$ rice hull and $0.20 \%$ betle leaf meal; $\mathrm{E}$ $=$ diet containing $10 \%$ rice hull and $0.20 \%$ betle leaf meal

Table 2

The chemical composition of diet (age 3 - 10 weeks)

\begin{tabular}{|c|c|c|c|c|c|c|c|}
\hline \multirow{2}{*}{$\begin{array}{l}\text { Chemical } \\
\text { components }\end{array}$} & \multirow{2}{*}{ Unit } & \multicolumn{5}{|c|}{ Treatments } & \multirow{2}{*}{$\begin{array}{l}\text { Standard: Scott } \\
\text { et al., (1982). }\end{array}$} \\
\hline & & A & B & $\mathrm{C}$ & $\mathrm{D}$ & E & \\
\hline $\begin{array}{l}\text { Metabolizable } \\
\text { energy }\end{array}$ & $\mathrm{kcal} / \mathrm{kg}$ & 2879.17 & 2826.25 & 2823.37 & 2812.49 & 2826.59 & $2800-2900$ \\
\hline Crude protein & $(\%)$ & 17.12 & 16.32 & 16.36 & 16.31 & 16.38 & $15-17$ \\
\hline Ether extract & $(\%)$ & 5.75 & 6.11 & 6.23 & 5.92 & 5.94 & $3-6$ \\
\hline
\end{tabular}

Partama, I. B. G., Yadnya, T. G. B., Trisnadewi, A. A. A. S., \& Sukada, I. K. (2018). Increasing nutrition value of fermented rice hull through biofermentation of lactobacillus complex bacteria supplemented. International Journal of Life Sciences, 2(2), 73-82. https://doi.org/10.29332/ijls.v2n2.179 


$\begin{array}{llllllll}\text { Crude fiber } & (\%) & 4,56 & 7,69 & 5,40 & 7,55 & 5,15 & 6-9 \\ \text { Calcium (Ca) } & (\%) & 1.0 & 0.95 & 0.96 & 0.95 & 0.96 & 0.80 \\ \text { Available } & (\%) & 0.80 & 0.65 & 0.52 & 0.58 & 0.60 & 0.45\end{array}$

phosphorus (P)

Notes:

$\mathrm{A}=$ control diet (without rice hull and betle leaf meal); $\mathrm{B}=$ diet containing $10.0 \%$ rice hull; $\mathrm{C}=$ diet containing $10 \%$ fermented rice hull; $\mathrm{D}=$ diet containing $10 \%$ rice hull and $0.20 \%$ betle leaf meal; $\mathrm{E}=$ diet containing $10 \%$ rice hull and $0.20 \%$ betle leaf meal

\section{Variables Observed}

Variable observed were nutrition value (crude protein, ether extract, crude fiber, nitrogen-free extract, ash, and gross energy), feed consumption, feed antioxidant capacity, ration consumption, ration digestibility, final body weight, body weight gain, feed conversion ratio, and blood antioxidant profile.

\section{Data Analysis}

Data were analyzed with analysis of variance if there were significant differences among the treatment analyzed continued using Duncan's Multiple Range Test $(\mathrm{P}<0.05)$ (Steel and Torrie, 1989).

\section{Results and Analysis}

The nutrition value of rice hull through biofermentation of Lactobacillus complex bacteria and supplemented with betle leaf meal is shown in Table 3.

Table 3

The nutrition value of fermented rice hull through biofermentation of lactobacillus complex bacteria supplemented with betle leaf meal

\begin{tabular}{lcc}
\hline Variable & Before fermentation & After fermentation \\
\hline Crude protein (\%) & 4.66 & 7.49 \\
Ether extract (\%) & 1.99 & 2.88 \\
Crude fiber (\%) & 43.59 & 21,01 \\
Nitrogen free extract (\%) & 8.66 & 19.01 \\
Ash & 16.41 & 23.53 \\
Gross energy (kcal/g) & 2.7636 & 3.1493 \\
\hline
\end{tabular}

In biofermentation process, urea change by urease enzyme to be $\mathrm{CO}_{2}$ and $\mathrm{NH}_{3}$ as a source of amino acid groups, and the EM-4 solution could produce cellulase, protease, and lipase enzyme (Wididana and Higa, 1993). Polichacarida in rice hull is changed to be oligosaccharide by cellulase enzyme, then to be disaccharide by maltase enzyme, and finally to be simple sugar compound. It causes the increasing of nitrogen-free extract from $8.66 \%$ to $19.01 \%$ and crude fiber decrease from $43.59 \%$ to $21.01 \%$. The existence of NH3 in urea hydrolysis will react through transamination and form a new amino acid (biochemical process ) (Murray et al., 2009) with the following reaction:



Hydroxy carboxylase acid Amino acid 
The existence of transamination causes the increasing of the crude protein content of rice hull from $4.66 \%$ to $7.49 \%$. and gross energy content from $2.7636 \mathrm{kcal} / \mathrm{g}$ to $3.1493 \mathrm{kcal} / \mathrm{g}$. The results of this study are appropriate with Yadnya et al. (2007) experiment which found that biofermentation in sawdust could increase crude protein and decrease crude fiber.

\section{Biofermentation of Rice Hull Supplemented with Betle Leaf Meal on Performance of Bali Duck}

The offering diets containing fermented rice hull through biofermentation of Lactobacillus complex bacteria supplemented with betle leaf meal on performance of Bali duck showed in Table 4.

Table 4

Biofermentation of lactobacillus complex bacteria supplemented with betle leaf meal on performance of Bali duck

\begin{tabular}{|c|c|c|c|c|c|c|}
\hline \multirow{2}{*}{ Variables } & \multicolumn{5}{|c|}{ Treatment $^{1)}$} & \multirow{2}{*}{$\mathrm{SEM}^{3)}$} \\
\hline & A & B & $\mathrm{C}$ & D & E & \\
\hline $\begin{array}{l}\text { Feed consumption } \\
\text { (kg/head) }\end{array}$ & 4.354 & 4.434 & 4.397 & 4.400 & 4.398 & 139.16 \\
\hline $\begin{array}{l}\text { Feed antioxidant } \\
\text { capacity (IC\%) }\end{array}$ & $3.97 c^{2)}$ & $3.26 \mathrm{c}$ & $4.96 \mathrm{~b}$ & $5.10 \mathrm{a}$ & $5.25 a$ & 1.016 \\
\hline $\begin{array}{l}\text { Ration digestibility } \\
(\%)\end{array}$ & $72.55 b c$ & $70.31 \mathrm{c}$ & $76.38 \mathrm{a}$ & 75.88ab & $76.68 a$ & 0.093 \\
\hline $\begin{array}{l}\text { Final body weight } \\
(\mathrm{kg} / \mathrm{head})\end{array}$ & $1.251 \mathrm{c}$ & $1.184 d$ & $1.328 \mathrm{a}$ & $1.287 \mathrm{~b}$ & $1.375 a$ & 11.191 \\
\hline $\begin{array}{l}\text { Body weight gain } \\
\text { (g/head) }\end{array}$ & $962.50 \mathrm{~d}$ & $898.50 \mathrm{e}$ & $1039.20 \mathrm{~b}$ & $999.20 \mathrm{c}$ & $1090.20 \mathrm{a}$ & 8.21 \\
\hline $\begin{array}{l}\text { Feed conversion ratio } \\
\text { (FCR) }\end{array}$ & $4.51 b$ & $4.93 a$ & $4.40 \mathrm{c}$ & $4.22 \mathrm{~d}$ & $4.07 \mathrm{e}$ & 0.01 \\
\hline
\end{tabular}

Notes :

1) $\mathrm{A}=$ control diet (without rice hull and betle leaf meal); $\mathrm{B}=\operatorname{diet}$ containing $10.0 \%$ rice hull; $\mathrm{C}=\operatorname{diet}$ containing $10 \%$ fermented rice hull; $\mathrm{D}=$ diet containing $10 \%$ rice hull and $0.20 \%$ betle leaf meal; $\mathrm{E}=$ diet containing $10 \%$ rice hull and $0.20 \%$ betle leaf meal

2) Values with different letters in the same row means significantly different $(\mathrm{P}<0.05)$

3) SEM: Standard Error of The Treatment Means

Feed consumption on treatment A was not significantly different $(\mathrm{P}>0.05)$ compared with treatment $\mathrm{B} C$, $\mathrm{D}$, dan $\mathrm{E}$ because the nutrient content provided for all treatments were in accordance with the standard rations of Scott et al. (1982). Wahju (1992) stated that the primary nutritional need for ducks is energy followed by other nutrient content.

Feed antioxidant capacity in the control diet (treatment A) is 3.97 IC\% (Table 4). Offering treatment B could decrease feed antioxidant capacity $17.63 \%$ lower than diet A, but not significantly different $(\mathrm{P}>0.05)$. Provision of treatment $\mathrm{C}, \mathrm{D}$, and $\mathrm{E}$ could increase significantly $(\mathrm{P}<0.05)$ the feed antioxidant capacity than treatment A, respectively 24.93\%; $28.46 \%$ and $32.24 \%$. The antioxidant compound could increase antioxidant capacity. Susila et al. (2016) reported that diet containing fermented Aspergillus niger and supplemented with Ipomoea batatas leaf meal could increase feed antioxidant capacity. Betle leaf containing betlephenol, sesquiterpene, and karvokiol (Agung, 2009) affected to feed antioxidant capacity. Provision control diet (treatment $A$ ) resulted ration digestibility is $72.55 \%$ (Table 4), treatment B decreased ration digestibility, but not significantly different $(\mathrm{P}>0.05)$ compared with treatment A. Provision of $\mathrm{C}, \mathrm{D}$, and E treatment could increase ration digestibility significant different $(P<0.05)$ than treatment $A$, respectively $5.27 \%, 4.58 \%$, and $5.69 \%$. Biofermentation of rice hull supplemented with betle leaf meal could increase the nutrition value, final body weight and give positive effect to the antioxidant capacity of Bali duck. The existence of enzymes in EM-4

Partama, I. B. G., Yadnya, T. G. B., Trisnadewi, A. A. A. S., \& Sukada, I. K. (2018). Increasing nutrition value of fermented rice hull through biofermentation of lactobacillus complex bacteria supplemented. International Journal of Life Sciences, 2(2), 73-82. https://doi.org/10.29332/ijls.v2n2.179 
solution and supplemented with betle leaf meal could increase feed antioxidant capacity, ration digestibility, and effect to the weight gain, final weight gain, and improve feed conversion ratio (FCR). The results of this study are consistent with those obtained by Susila et al. (2016). Yadnya et al. ( 2012) reported that biofermentation of Ipomoea batatas L. skin by Aspergillus niger could improve antioxidant capacity and final body weight, ration digestibility causes effect the body weight gain (Yadnya et al., 2012).

Rice hull biofermentation of Lactobacillus complex bacteria supplemented with betle leaf meal on blood antioxidant profile of Bali duck

Table 5

Rice hull biofermentation of lactobacillus complex bacteria supplemented with betle leaf meal on blood antioxidant profile of Bali duck

\begin{tabular}{|c|c|c|c|c|c|c|}
\hline \multirow{2}{*}{ Variables } & \multicolumn{5}{|c|}{ Treatment $^{1)}$} & \multirow{2}{*}{ SEM $^{3)}$} \\
\hline & $\mathrm{A}$ & $\mathrm{B}$ & $\mathrm{C}$ & $\mathrm{D}$ & $\mathrm{E}$ & \\
\hline Antioxidant ca & $34.9 c^{2)}$ & $41.14 \mathrm{~b}$ & $49.28 \mathrm{a}$ & $50.30 \mathrm{a}$ & $51.89 a$ & 0.8494 \\
\hline Superoxide dismutase $(\mu / \mathrm{ml})$ & $0.660 \mathrm{e}$ & $0.7675 \mathrm{~d}$ & $0.830 \mathrm{c}$ & $0.8875 b$ & $0.945 a$ & 0.0142 \\
\hline Malondialdehide (mmol/g) & $3.445 \mathrm{a}$ & $3.1125 b c$ & $3.1625 \mathrm{~b}$ & $2.827 \mathrm{c}$ & $2.155 \mathrm{~d}$ & 0.0486 \\
\hline
\end{tabular}

Notes :

1) $\mathrm{A}=$ control diet (without rice hull and betle leaf meal); $\mathrm{B}=$ diet containing $10.0 \%$ rice hull; $\mathrm{C}=$ diet containing $10 \%$ fermented rice hull; $\mathrm{D}=$ diet containing $10 \%$ rice hull and $0.20 \%$ betle leaf meal; $\mathrm{E}=$ diet containing $10 \%$ rice hull and $0.20 \%$ betle leaf meal

2) Values with different letters in the same row means significantly different $(\mathrm{P}<0.05)$

3) SEM: Standard Error of The Treatment Means

Bali duck fed with diet control (treatment A) produced 34.90 IC\% antioxidant capacity (Table 5). Provision of treatment $B, C, D$, and E could increase significantly $(\mathrm{P}<0.05)$ the blood antioxidant capacity compared to treatment A. Diet containing high antioxidant capacity could neutralize the free radical (Kumalaningsih, 2008), so treatment B, C, D, and E could increase the value of blood antioxidant capacity. Susila et al. (2016) reported that offered of rice hull fermented with Aspergillus niger and supplemented with Ipomoea batatas L. could increase meat antioxidant capacity which is caused by increasing of feed antioxidant capacity content. Provision of treatment A resulted in superoxide dismutase (SOD) $0.66 \mu / \mathrm{ml}$ (Table 5). Bali duck fed treatment $\mathrm{B}, \mathrm{C}, \mathrm{D}$, and $\mathrm{E}$ could increase SOD significant $(\mathrm{P}<0.05)$ higher compared with treatment $\mathrm{A}$. Susila et al. (2016) reported that offering diets containing rice hull fermented by Aspergillus niger and supplemented with Ipomoea batatas L. leaf meal could increase level of meat SOD of Bali duck. Sumardika and Jawi (2011) reported that offering Ipomoea batatas L. leaf extract in diet could increase level SOD of rat blood serum. Blood Malondialdehyde (MDA) on treatment A is $3.445 \mathrm{mmol} / \mathrm{g}$ (Table 5). Offering diets on treatment $\mathrm{B}, \mathrm{C}, \mathrm{D}$, and $\mathrm{E}$ could decrease blood MDA significantly $(\mathrm{P}<0.05)$ compared with treatment $\mathrm{A}$. Decreasing of MDA level in the blood has a correlation to improve antioxidant capacity (Yadnya et al., 2015). This is in accordance with the result of Susila et al. (2016) experiment which offered fermented rice hull supplemented with Ipomoea batatas L. leaf could increase the antioxidant capacity and superoxide dismutase, but decrease malondialdehyde significantly $(\mathrm{P}<0.05)$.

\section{Conclusion}

From the results of this study, it could be concluded that fermented rice hull through biofermentation of lactobacillus complex bacteria supplemented with Piper betle leaf meal could improve the nutrition value, performance, and blood antioxidant profile of Bali duck. 
Conflict of interest statement and funding sources

The authors declared that they have no competing interest. The study was financed by the Ministry of Technology Research and Higher Education the Republic of Indonesia.

\section{Statement of authorship}

The authors have a responsibility for the conception and design of the study. The authors have approved the final article.

\section{Acknowledgments}

The author would like to thank Directorate General of Empowerment Research and Development, The Ministry of Technology Research and Higher Education the Republic of Indonesia for the fund through Rector and Institute for Research and Community Service Udayana University Contract Agreement Number: 415.39/UN.4.A/PL/2017, March 30, 2017.

Partama, I. B. G., Yadnya, T. G. B., Trisnadewi, A. A. A. S., \& Sukada, I. K. (2018). Increasing nutrition value of fermented rice hull through biofermentation of lactobacillus complex bacteria supplemented. International Journal of Life Sciences, 2(2), 73-82. https://doi.org/10.29332/ijls.v2n2.179 


\section{References}

1. Agung, I. G. N. (2011). Time series data analysis using EViews. John Wiley \& Sons. View in (Google Scholar)

2. Bidura, I. G. N. G. (2007). Aplikasi Produk Bioteknologi Pakan Ternak. Universitas Udayana, Denpasar. View in (Google Scholar)

3. Dewi, N. N. A., \& Mustika, I. W. (2018). Nutrition Content and Antioxidant Activity of Black Garlic. International Journal of Health Sciences (IJHS), 2(1), 11-20.

View in (Google Scholar)

4. Kumalaningsih, S. (2008). Antioksidan SOD (Super Oksida Dismutase). Anti Oxidant Center. com. http:/antioksidancenter. com [10 Januari 2008].

View in (Google Scholar)

5. Lubis, D. A. (1992). Ilmu makanan ternak umum. Penerbit PT. Pembangunan. Jakarta. View in (Google Scholar)

6. Murray, L. J., Dincă, M., \& Long, J. R. (2009). Hydrogen storage in metal-organic frameworks. Chemical Society Reviews, 38(5), 1294-1314.

View in (Google Scholar)

7. Nuriyasa, I. (1998). Pengaruh pemberian EM-4 (Effective microorganism-4) terhadap produksi berat kering dan daya cerna enzim pankreas babi pada umbi ketela pohon.

View in (Google Scholar)

8. Ogu, G. I., \& Orjiakor, P. I. (2017). Microbiological and Nutritional Qualities of Fermented Melon Seed Shells. International Journal of Life Sciences (IJLS), 1(2), 1-9.

View in (Google Scholar)

9. Roni, N. G. K., Sukmawati, N. M., \& Sriyani, N. L. P. (2006). Pengaruh Pemberian Ransum Mengandung Sekam Padi Diamoniasi disuplementasi dengan Zat Probiotik terhadap Bobot Badan, Perlemakan Tubuh, dan Karkas Ayam Broiler. Laporan Penelitian, Fakultas Peternakan, Universitas Udayana.

View in (Google Scholar)

10. Saxena, A. (2017). The Impact of Nutrition on the Overall Quality of Life Adolescent Girls are Living Across the City of Kota. International Journal of Life Sciences (IJLS), 1(1), 40-48.

View in (Google Scholar)

11.Scott, A. P., \& Baynes, S. M. (1982, August). Plasma levels of sex steroids in relation to ovulation and spermiation in rainbow trout (Salmo gairdneri). In Proceedings of the International Symposium on Reproductive Physiology of Fish (pp. 103-106). Pudoc Wageningen.

View in (Google Scholar)

12. Steel, K. P., \& Barkway, C. H. R. I. S. (1989). Another role for melanocytes: their importance for normal stria vascularis development in the mammalian inner ear. Development, 107(3), 453-463.

View in (Google Scholar) 
13. Sumardika, I. W., \& Jawi, I. M. (2011, September). Pengaruh pemberian ekstrak daun ubi jalar ungu (Ipomoea batatas L) terhadap profil lipida dan superoksida dismutase (SOD) serum darah mencit. Prosiding International. In 3rd International Conference on Biociences and Biotechnology, Bali. September (pp. 21-22).

View in (Google Scholar)

14.Susila, A. V., \& Balasubramanian, V. (2016). Correlation of elution and sensitivity of cell lines to dental composites. Dental Materials, 32(3), e63-e72.

View in (Google Scholar)

15. Suwidjayana, I. N., \& Bidura, I. G. N. G. (1999). Khasiat Ragi Tape dan Effective Microorganisme Menurunkan Kolesterol dan Lemak Karkas Itik. Laporan Penelitian Dosen Muda. Ditbinlitabmas, Fapet Unud, Denpasar.

View in (Google Scholar)

16. Wahju, J. (1992). Ilmu Nutrisi Ternak Unggas. UGM-Press. Yogyakarta.

View in (Google Scholar)

17. Walker, A. D. M. (2013). Plasma waves in the magnetosphere(Vol. 24). Springer Science \& Business Media. View in (Google Scholar)

18. Wididana, G. N., \& Higa, T. (1993). Penuntun Bercocok Tanam Padi dengan Teknologi dengan Teknologi Effective Microrganism-4 (EM-4). Seri Pertanian Akrab Lingkungan.

View in (Google Scholar)

19. Yadnya, T. B., Trisnadewi, A. A. A. S., Sukada, I. K., \& Oka, I. G. L. (2016). The Effect of Fermented Purple Sweet Potato (Ipomoea batatas L) Skin in Diets on Feed and Anthocyanin Consumption, Carcass Characteristics, Anthioxidant Profile and Meat Texture of Bali Duck. Journal of College and University. This is an open access article under the, 2454, 2261.

View in (Google Scholar)

20.Yadnya, T. G. B., Partama, I. B. G., \& Trisnadewi, A. A. A. S. (2012). Pengaruh pemberian ransum yang mengandung ubi jalar ungu (Ipomoea batatas L) terfermentasi Aspergillus niger terhadap kecernaan ransum, retensi protein, dan pertambahan bobot badan itik bali. Prosiding Semnas FAI.

View in (Google Scholar)

21.Yadnya, T. G. B., Sukmawati, N. M. S., \& Budiasa, I. K. M. (2007, July). Pengaruh pemberian serbuk gergaji kayu yang diamoniasi terfermentasi dan daun salam dalam ransum terhadap penampilan, karkas dan kadar kolesterol darah itik bali. In Prosiding Seminar Nasional, Fakultas Peternakan, UGM, Yogyakarta (pp. 24-27).

View in (Google Scholar)

Partama, I. B. G., Yadnya, T. G. B., Trisnadewi, A. A. A. S., \& Sukada, I. K. (2018). Increasing nutrition value of fermented rice hull through biofermentation of lactobacillus complex bacteria supplemented. International Journal of Life Sciences, 2(2), 73-82. https://doi.org/10.29332/ijls.v2n2.179 


\section{Biography of Authors}

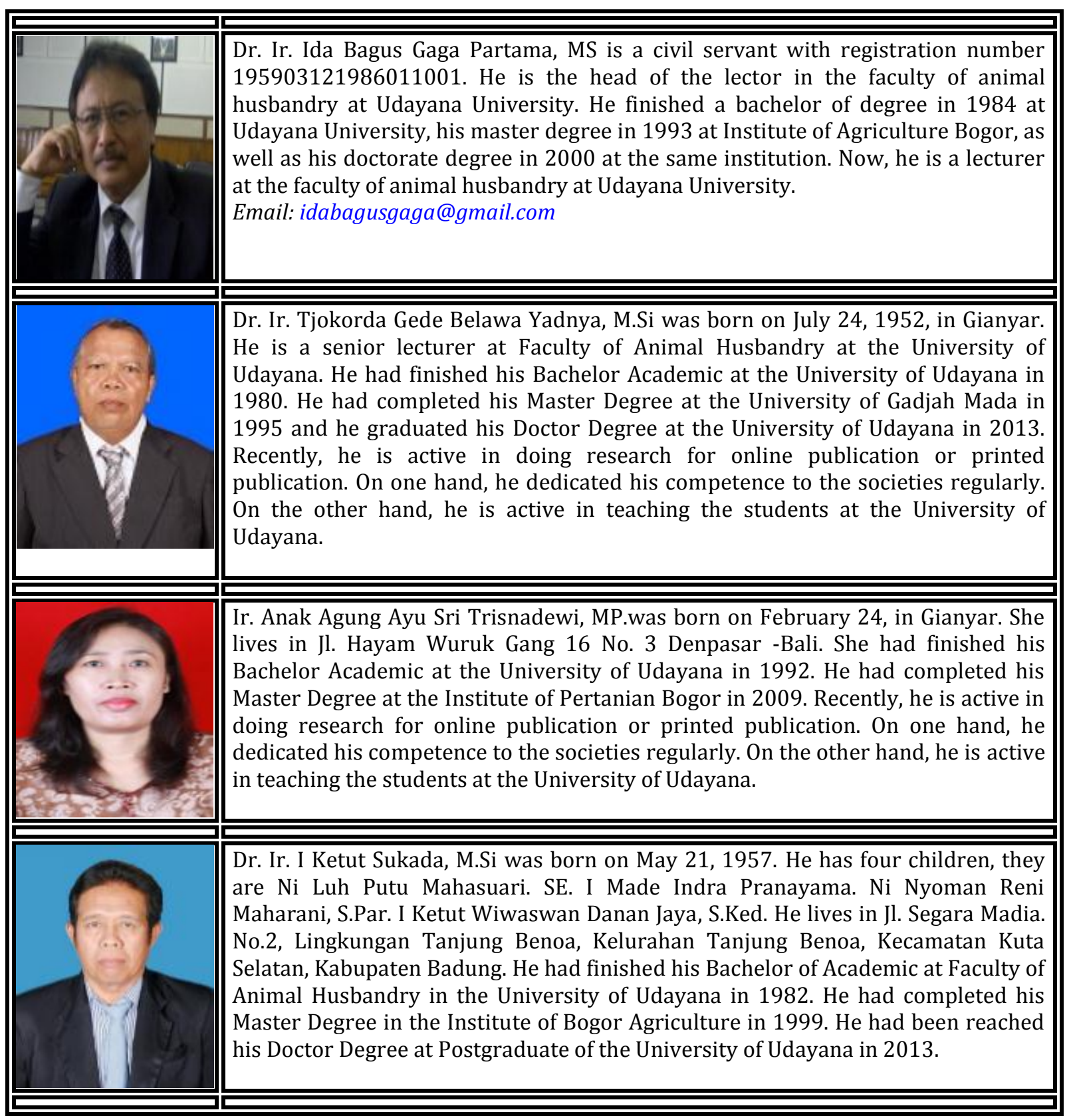

